\title{
Voices From The United Arab Emirates: Engineering Graduates' Labour Market Requisite Competencies
}

Tharwat M. EL-Sakran, American University of Sharjah, United Arab Emirates Asmaa Awad, University of Sharjah, United Arab Emirates

\begin{abstract}
This study reports on engineering graduates' labour market requisite communication competences and skills in the work environment in the United Arab Emirates (UAE). Its main purpose was to investigate whether internationally required engineering graduates' communication competences were the same in third world countries or different. It used a survey to collect responses from major engineering companies operating in the seven emirates federation forming the UAE. The researchers conducted semi-structured interviews with some of the participants to seek clarifications on some of the survey responses. Results indicted similar market demands to those reported in international research with differences in preferences and ranking of competences. The conclusions reported are based on the responses given in the surveys. Future research may follow up some engineering graduates and find out how they perform in labor market environments. The findings show that although engineering labor market demands are in line with global market demands, they; nevertheless, indicate differences in the ranking and importance of the required competences and skills. This has significant implications for engineering course designers.
\end{abstract}

Keywords: Global Engineer; Engineering Labor Market Demands in UAE; Engineering Communication; Engineering Graduates' Competences \& Skills

\section{INTRODUCTION}

ngineering graduates' requisite communication competencies and skills have been of interest to higher
education accreditation agencies, academicians, researchers and the industry all over the world. The past
three decades have witnessed an increasing number of engineering job requirements surveys publishing details of employability skills employers seek in their prospective engineers. Some such studies (Australian Council for Educational Research, 2001; Hill \& Petty, 1995; Holden \& Hamlett, 2007; Levenson, 2000; Patil \& Codner, 2007; Prescott et al., 2012; etc.) have noted that employers stress that prospective engineers should entertain and demonstrate the following employability skills:

1) Efficient oral and written communication skills

2) Interpersonal skills with colleagues and clients

3) Leadership skills

4) Problem-solving skills

5) A clear understanding of social responsibility and ethical practices

6) Emotional intelligence

7) Ability to take initiative

8) Time management skills

9) Ability to work under pressure

10) Teamwork skills and ability to work in multidisciplinary and multicultural teams

11) "Global mobility" (Patil and Godner, 2007, p. 649). 
As a result and in line with the calls for mobile global engineering graduates and the requirements of the Accreditation Board for Engineering and Technology (ABET), engineering colleges have become increasingly aware of the need to provide more than the traditional technical discipline-based education for their students, realizing the fact that sound knowledge of engineering theory and practice alone is no longer sufficient to meet the demands of the market place. Consequently, students graduating from engineering programs are expected to have an effective range of communication skills and to have developed collaborative work practices to meet labor market demands.

However, research (e.g., Wickramasinghe \& Perera, 2010) suggests that employability skills may vary from one region to another and from one company to another. Therefore, it is the purpose of this study to probe into engineering labour market requirements from newly graduated engineers in the United Arab Emirates (UAE); a region classified as a third world developing country. The UAE is located on the crossroads between East and West and hosts a vast number of national, multinational and international engineering companies. It is expected that the findings will reveal engineering companies' communication requirements in the United Arab Emirates and guide engineering syllabus designers to make courses responsive to local and global market requisite communication needs and skills. The research aims to find answers to the following questions:

\section{Research Questions}

1. What employability skills do engineering companies employers in the UAE want new recruits to have?

2. Are these different from those reported on in internationally published peer-reviewed research?

\section{METHODOLOGY}

\section{Data Collection Tools \& Procedures}

For the purposes of this research, a survey was designed and deployed via the Surveymonkey. com site to 100 engineering companies based in the seven emirates, which form the United Arab Emirates Federation. The survey items were based on labor market requisite employability skills and communication competencies recurrent in engineering communication and education research (e.g., Ashman, Scrutton, Stringer, Mullinger, \& Willison (2008); Kaewpet (2011); Male, Bush \& Chapman (2010); Spinks, Silburn, \& Birchall (2006); Martin, Maytham, Case, \& Fraser (2005) Rychen and Salganik (2003); Perusich, Davis, Laware, \& Taylor (2007, TSE-2 ); Wickramasinghe \& Perara (2010)). The survey consisted of 10 major questions (see Appendix) as follows: (1) demographics, and (2) ranking the desired communication competences and skills in engineering graduates in terms of their importance, (3) formal and informal communication activities that take place in the engineering companies surveyed, and a two four-point Likert Scale questions, ranging from Strongly agree (4), Agree (3), Disagree (2) to Strongly disagree (1), in addition to a column titled "Non-applicable" in case some of the respondents viewed that (a) statement(s) expressed ideas that they were not applicable or required in new recruits. The statements (see appendix) requested the participants to rate newly recruited engineering graduates in terms of certain personality attributes and workplace requisite communication skills, such as problem-solving, self-confidence, teamwork skills and written and oral communication skills, etc.

The responses to each of the statements included in the two Likert-Scale questions are counted and presented in the results section of this paper as percentages. These refer to the numbers of respondents who marked the choices given; that is, "Strongly agree" "Agree", "Disagree", "Strongly disagree" or "Not applicable". In all cases, the combined number of those who ticked "strongly agree and "agree" for a given statement was divided by the total number of participants in the survey. The survey also contained the following two questions:

\footnotetext{
- $\quad$ Have you ever encountered a situation where you have had to offer the newly recruited engineers in-house training to improve their employability skills (communication or personality traits)? If yes, what issues did you cover?

- $\quad$ Do you think universities should pay more attention to employability skills and personality attributes along with the academic ones? If yes, how?
} 
Reminders were sent to all employers on a weekly basis for a period of eight weeks. The overall response was 41. The survey questions were prepared by the two authors and the survey itself was uploaded on Surveymonkey and deployed by the second author. In a few cases, the authors had to conduct some semi-structured interviews to clarify responses given in the survey.

\section{Participants}

Forty one (41) senior ranking and experienced engineers working in key positions in several UAE-based companies responded to the survey questions and statements. Their percentages, in terms of company activities were: $4.9 \%$ from manufacturing companies, $39 \%$ from construction companies, $26.8 \%$ from high tech companies and 29.3\% from a host of companies dealing in other engineering activities. The participants consisted of 16 females and 25 males. They all had been involved in interviewing, recruiting and closely supervising a good number of engineering graduates ranging from $5.0 \%$ to $57.5 \%$ as shown in Table 1 below:

Table 1: Numbers of recently recruited engineers in the companies surveyed

\begin{tabular}{|c|c|}
\hline Numbers of recent recruits & Percentages \\
\hline $0-5$ & 57.5 \\
\hline $6-10$ & 25.0 \\
\hline $11-15$ & 5.0 \\
\hline $15+$ & 12.5 \\
\hline
\end{tabular}

The participants represent national, international and multi-national engineering companies actively involved in the UAE engineering environment.

\section{RESULTS}

Although the combined responses (i.e., strongly agree and agree) show that newly recruited engineers exhibit excellent internet surfing skills (81.3\%) and a good sense of work ethics (97.1\%), they also indicate deficiencies in fresh engineering graduates' oral and written communication skills and some other personal attributes as will be detailed below. $60 \%$ of the respondents report that newly recruited engineers can neither take initiative nor handle activities that need critical thinking skills without help and assistance from senior engineers. Percentages also show that new recruits lack good management skills (54.9\%), problem solving skills (50.9\%) and are not reliable, a serious claim that was further investigated in the semi-structured interviews. It was explained as: "We cannot give them a task and leave them work on their own; they still need to be kept under direct and close supervision until they learn the way things are done in the work environment". Results also show that new recruits are not able to prepare and keep work e-portfolios $(53.3 \%)$, an issue that previous research overlooked. Furthermore, $70 \%$ stated that new recruits have sound engineering knowledge, but still do not know how to implement it in real life situations.

Conversely, $84.3 \%$ say that their new recruits are able to work in teams, punctual (72.2\%), flexible (76.4\%), dress appropriately for the job (82.3\%), innovative (70\%) and can work under pressure (71.6\%). Yet, as far as new engineering recruits` oral and written communication skills are concerned, the responses show deficiencies in their ability to appropriately write and structure a technical report (73.2\%), memos (78\%) and produce audience sensitive formal email messages $(100 \%)$. Furthermore, respondents claim that new recruits need politeness strategies and good English to actively participate in company social gatherings (61.0\%), informal staff meetings (73.2\%), formal company discussions (85.4\%) and engage in phone conversations with clients (75.6\%). When asked to rank oral communication skills that new recruits direly need, the respondents listed presentation skills as number 1 and active participation in workshops as number 2.

In response to the question: Do you supply in-house training to make up for some of the competences that new recruits lack, $40.6 \%$ have stated that they do. They have also added that such training deals with:

- $\quad$ Production of well-written technical reports.

- $\quad$ Efficient oral communication skills in English.

(C) 2012 The Clute Institute http://www.cluteinstitute.com/ 
- $\quad$ Problem-solving techniques.

- $\quad$ Time management skills.

- $\quad$ Etiquettes for dealing with customers.

In response to the question: What do you think engineering colleges should do to help you? , 90.3\% remarked that universities should, in addition to supplying field-specific engineering knowledge, focus more on:

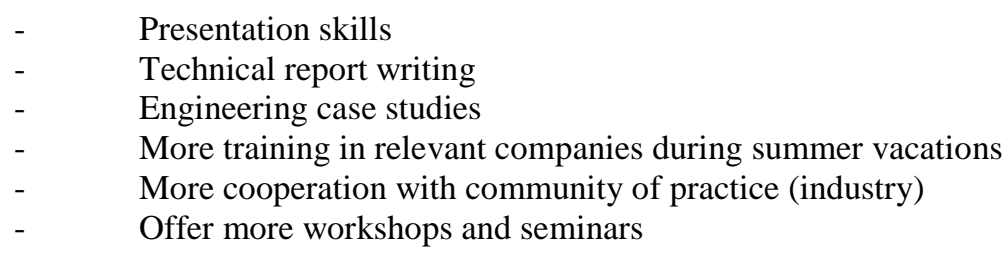

Although $61 \%$ of the respondents were males and $39 \%$ were females, all reported similar perceptions of deficiencies; that is, no gender differences were found in the responses. Since the data did not follow any distribution, validity of statistical tests becomes questionable. Furthermore, the small number of participants from both genders would not provide reliable results. However, looking at the graphical representation of the data (see below), it can be argued that there is no noticeable difference(s) between the respondents in terms of their gender. For example, in the response to the statement on dress code, both male and female respondents reported similar perceptions (see Fig. 1 below). Figure 2 shows similar responses to the statement on engineering graduates' problem-solving ability. This may indicate that both male and female respondents, being in professional managerial positions for long periods and aware of work environment requirements, know exactly, regardless of their gender, what skills new recruits should possess to appropriately function in today's engineering labour market environment.

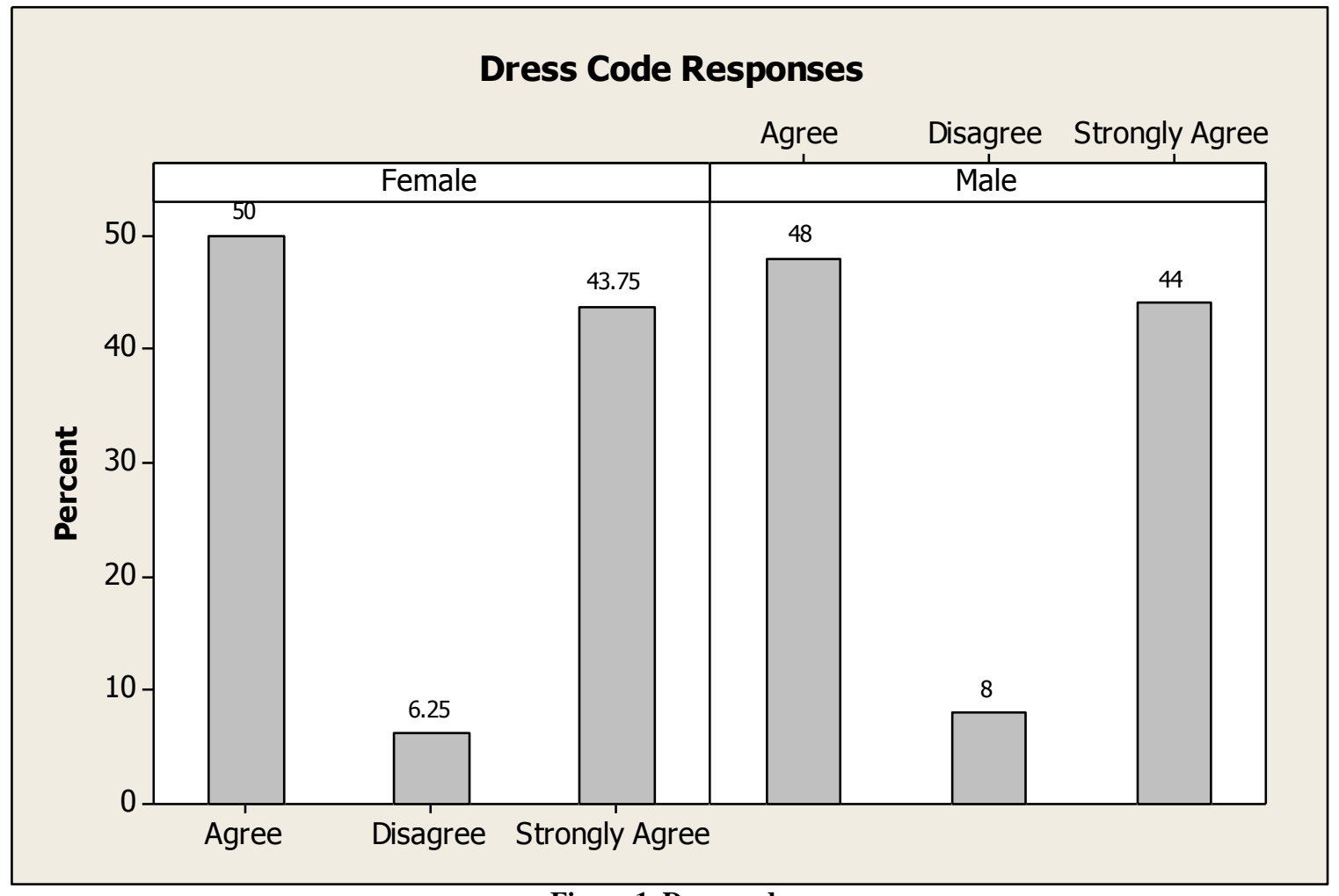

Figure 1. Dress code 


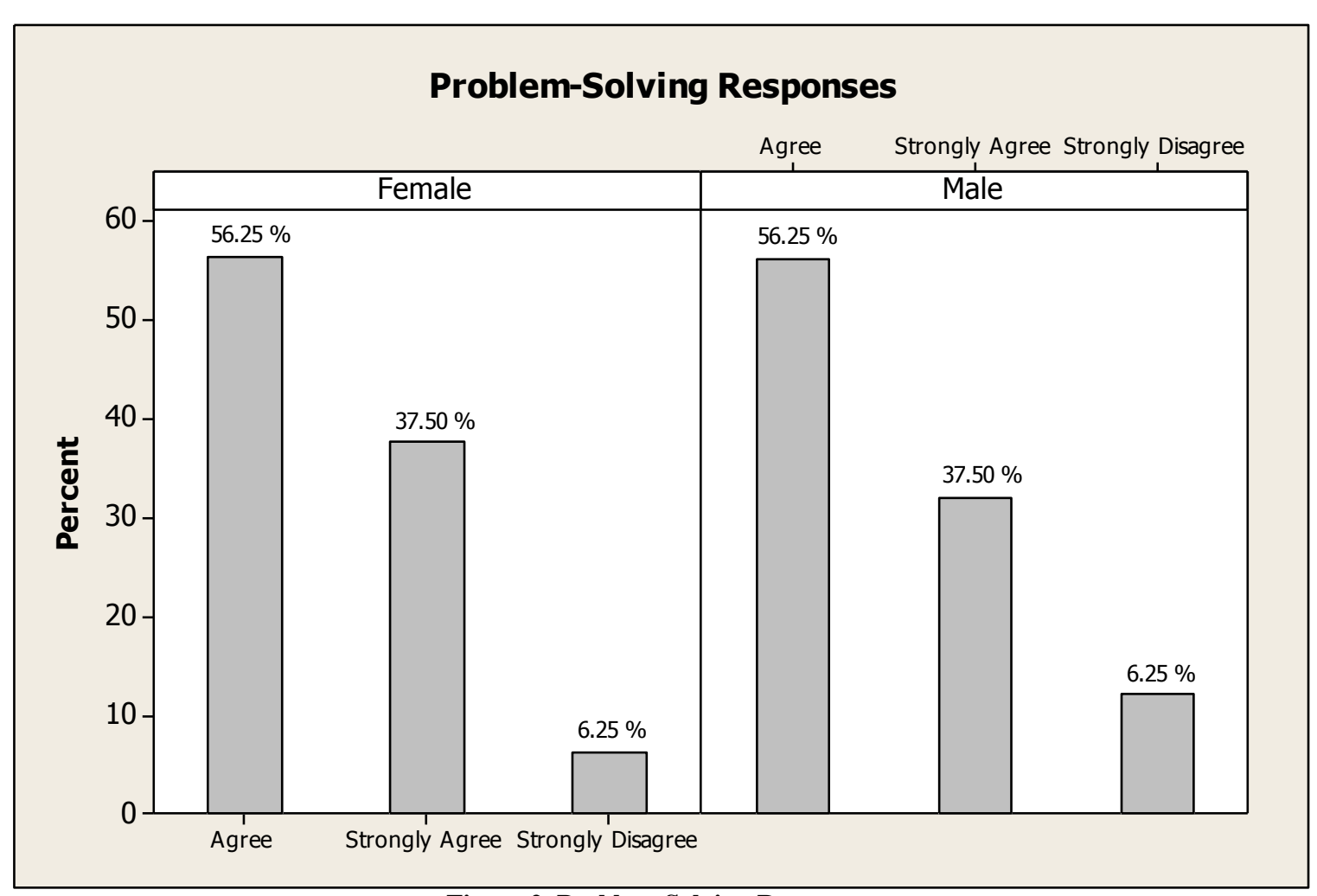

Figure 2. Problem-Solving Responses

\section{DISCUSSION AND RECOMMENDATION}

It is no surprise that the reported results corroborate international research findings concerning new recruits' communication shortcomings and deficiencies in personality attributes. This, we believe, may be the result of the world becoming more of a global village and the wide spread of international and multinational companies all over the world because of cheap labor and, maybe, better markets and outlets. The only differences noted are in the ranking of the required skills. For instance, effective and efficient communication skills in both oral and written English are given priority over others. This may have been a result of the English language becoming the lingua franca in various non-English speaking countries (Kassim \& Ali, 2010) and the surveyed companies' connections with mother companies abroad. This may also be the reason for many companies in the region only wanting to recruit engineering graduates of foreign English language medium universities operating in the UAE, a point which calls for further investigation.

It seems that whatever universities do, there will always be a gap between graduates` level of competences and practices in the work place. Research (e.g., Amare \& Brammer, 2005) indicates that there is a difference in practice between what universities do as far as communication skills are concerned and what really happens in the labor market. This calls for greater co-operation between academy and industry to close any existing gaps between what is taught in universities and what is practiced in the work environment. Colleges of engineering in non-English speaking countries should recognize the fact that English fluency is a necessary condition for success in a global economy (Kaewpet, 2011). Therefore, a strong emphasis should be placed on developing excellence in communication skills, both written and oral, an important issue that should be accorded extra focus in non-English speaking countries.

The above results point to the need for including more communication and humanity focused courses in the engineering curriculum or, if not possible, embedding the required competences in engineering courses and making them an integral part of their learning objectives. For instance, engineering instructors could ask students to give oral presentations of course projects to develop and enhance students' presentation skills. They could also require 
students to organize students' conference in which they report and present their research project results. This should be coupled with a requirement that students present well-structured written reports. Closing and/or narrowing the gap between engineering instructors', English language communication specialists' and engineering company managers' perceptions of labour market communication requirements will only take place when close cooperation and coordination materializes between the three parties. This could be negotiated and implemented during students' internship periods. The first two parties may pay visits to interns and obtain first-hand information on the type(s) of communication activities the companies providing the training uses. On a related note, internship periods need to be extended to provide students ample opportunities to apply their classroom learning to field-related problems; that is, relate theory to practice and become aware of work environment requirements.

To conclude, professional communication skills (presentation skills; writing proposals; writing reports; writing calls for meetings; preparing meeting agendas; minute-taking; documenting decisions; writing formal email messages (Wang \& Aaltonen, 2004) and writing memos (Amare \& Brammer, 2005)) should be given precedence in communication courses and other engineering courses. Teaching all employability skills in one course may be a near impossible mission. Employability skills should also feature in colleges' comprehensive exit exams to ensure that graduating students have attained the required skills and attributes and meet the characteristics of a "global engineer" (Grandin and Hirleman, 2009). Comprehensive exit exams may also include an oral component for which practicing engineering managers could be invited to participate in. That is, they may become members of oral exam committees and ascertain that graduating students meet workplace requirements. Besides, colleges of engineering should involve the industry (e.g., Zinser, 2003) in the decision making process by asking them to report on the performance of recently employed graduates and whether they satisfy labor market needs or not and communicate any shortcomings.

\section{AUTHOR INFORMATION}

Dr. Tharwat M. EL-Sakran is a professor of linguistics in the English Department at the American University of Sharjah in the United Arab Emirates. He has published several papers on teaching English for specific purposes, cross-cultural communication, translation and interpreting and discourse analysis. He is also the author of a book titled 'News Translation: Strategies and Techniques' and the co-author of three other books titled 'English for Media', 'Bank Translators', and 'The Study of Language'. His research interests are in the fields of: Teaching English for Specific Purposes (TESP), contrastive linguistics, TEFL/TESOL, pragmatics, translation and discourse analysis. He could be contacted at the following email address: telsakran@ aus.edu (Corresponding author)

Dr. Asmaa Awad is an assistant professor in the English Department in the University of Sharjah, Sharjah, United Arab Emirates. Dr. Awad has participated and presented in national and international conferences on teaching English as a foreign and second language. She has been teaching English language skills to tertiary level students in the United Arab Emirates for the past 15 years. Her research interests include: TEFL, TESP and Computer-based communication. Dr. Awad could be contacted at the following email address: aawad@sharjah.ac.ae

\section{REFERENCES}

1. Accreditation Board for Engineering and Technology Inc. (ABET). Retrieved from: http://www.abet.org/

2. Amare, N. \& Brammer, C. (2005). Perceptions of memo quality: A case study of engineering practitioners, professors, and students. Journal of Technical Writing and Communication, 35 (2), 179-190.

3. Ashman, P. J., Scrutton, S., Stringer, D., Mullinger, P. J. \& Willison, J. (2008). Stakeholder Perceptions of Chemical Engineering Graduate Attributes at the University of Adelaide. Proc. Chemeca. Newcastle City Hall: New South Wales, Australia.

4. Australian Council for Educational Research (2001). Gaduate skills assessment: Summary report, GSA Exit 2000, Camberwell, Vic.: ACER.

5. Grandin, J. M. and Hirleman, E. D. (2009). Educating Engineers as Global Citizens: A Call for Action /A Report of the National Summit Meeting on the Globalization of Engineering Education. Online Journal for Global Engineering Education: 4: Iss. 1, Article1. Retrieved from:

http://digitalcommons.uri.edu/ojgee/vol4/iss1/1 
6. Hill, R. \& Petty, G. (1995). New look at selected employability skills: A factor analysis of the occupational work ethic. Journal of Vocational Education Research, 20(4), 59-73.

7. Holden, R. \& Hamblett, J. (2007). The transition from higher education into work: Tales of cohesion and fragmentation. Education + Training, 49 (7), 516-585.

8. Kaewpet C. (2011). Learning needs of Thai civil engineering students. The Asian ESP Journal, 7(3), 80106.

9. Kassim, H. \& Ali, F. (2010). English communicative events and skills needed at the workplace: Feedback from the industry. English for Specific Purposes, 29, 168-182.

10. Kuenzi, J. J. (2008). CRS Report for Congress: Science, Technology, Engineering and Mathematics (STEM) Education: Background, Federal Policy, and Legislative Action. Congressional Research Service, Washington DC.

11. Levenson, L. (2000), Disparities in perceptions of generic skills- Academics and employer. Industry and Higher Education, pp.157-163.

12. Male, S. A., Bush, M. B. \& Chapman, E. S. (2010). Perceptions of competency deficiencies in engineering graduates. Australasian Journal of Engineering Education, 16 (1), 55-67.

13. Martin, R., Maytham, B., Case, J. \& Fraser, D. (2005). Engineering graduates' perceptions of how well they were prepared for work in industry. European Journal of Engineering Education, 30 (2), 167-180.

14. Patil, A. \& Codner, G. (2007). Accreditation of engineering education- review, observations and proposal for global accreditation. European Journal of Engineering Education, 32, (6) 639-651.

15. Perusich, K., Davis, B., Laware, G. \& Taylor, K. (2007). Assessing Teamwork for Accreditation: Understanding What Needs to be Known and Its Integration into Engineering and Technology Curricula. Proceedings from the $37^{\text {th }}$ ASEE/IEEE Frontiers in Education Conference, Session T3E, Milwaukee, WI.

16. Prasad, G. and Bhar, C. (2010). Accreditation system for technical education programmes in India: A critical review, European Journal of Engineering Education. 35 (2), 187-213.

17. Prescott, D. L., El-Sakran, T., Al-Assaf, Y., Albasha, L. \& Aloul, F. (2012). Teambuilding, Innovation and the Engineering Communication Interface. American Journal of Engineering Education, 3(1), 1-12.

18. Rychen, D. S. \& Salganik, L. H. (Eds.), (2003). Key competencies for a successful life and a well functioning society. Cambridge: MA, Hogrefe \& Huber.

19. Spinks, N., Silburn, N. \& Birchall, D. (2006). Educating engineers for the $21^{\text {st }}$ century: The industry view. Royal Academy of Engineering, London. Retrieved from: www.raeng.org.uk/news/releases/henley/default.htm?print=true(accessed

20. Wang, M \& Aaltonen, S. (2004). Sino-Finnish e-mail project: A teaching tool for tertiary business communication course. Asian EFL Journal, 6 (3).

21. Wickramasinghe, V. and Perera, L. (2010). Graduates', university lecturers' and employers' perceptions towards employability skills. Education + Training, 52(3), 225-244.

22. Zinser, R. (2003). Developing career and employability skills: A US case study. Education + Training, 45 (7), 402-410. 


\section{Appendix}

Question 1: Please fill the following information (optional)

Name:

Age:

Gender:

City:.

Question 2: Describe your type of company or business.
a. construction
b. high tech
c. manufacturing
d. others (please specify)

Question 3: What is the number of engineering graduates recruited recently in your company?
a. $0-5$
b. $6-10$
c. $10-15$
d. $15+$

Question 4: What types of FORMAL oral communication occur in your company? (please check all that are relevant)
a. presentations
b. interviews
c. workshops
d. speeches
e. seminars

Question 5: What types of INFORMAL oral communication occur in your company? (please check all that are relevant)
a. staff meetings
b. social gatherings
c. discussions
d. phone calls

Question 6: What types of written communication occur in your company? (please check all that are relevant)
a. emails
e. proposals
h. technical reports
b. letters
f. summaries
i. application forms
c. memos
g. surveys
j. newsletters
d. advertisements
e. 
Question 7: Please rank the newly recruited engineers' effectiveness of/in the following areas of communication.

\begin{tabular}{|c|c|c|c|c|c|}
\hline Communication area & $\begin{array}{c}\text { Strongly } \\
\text { agree }\end{array}$ & Agree & Disagree & $\begin{array}{l}\text { Strongly } \\
\text { disagree }\end{array}$ & N/A \\
\hline $\begin{array}{l}\text { New recruits are able to give a good impression in a job } \\
\text { interview }\end{array}$ & & & & & \\
\hline New recruits have good presentation skills & & & & & \\
\hline New recruits are able to evaluate and interpret information & & & & & \\
\hline New recruits are able to fill out an application form & & & & & \\
\hline New recruits are able to work in groups & & & & & \\
\hline $\begin{array}{l}\text { New recruits are able to apply engineering knowledge to } \\
\text { the job }\end{array}$ & & & & & \\
\hline $\begin{array}{l}\text { New recruits are able to produce effective technical } \\
\text { reports }\end{array}$ & & & & & \\
\hline $\begin{array}{l}\text { New recruits are able to write a survey/questionnaire to } \\
\text { explore primary resources }\end{array}$ & & & & & \\
\hline New recruits are able to write an accurate memo & & & & & \\
\hline $\begin{array}{l}\text { New recruits are able to prepare a portfolio (a file contains } \\
\text { examples of work) }\end{array}$ & & & & & \\
\hline New recruits are able to summarize information & & & & & \\
\hline $\begin{array}{l}\text { New recruits are able to use websites, check and answer } \\
\text { emails regularly }\end{array}$ & & & & & \\
\hline
\end{tabular}

Question 8: Please rank the newly recruited engineers' effectiveness of/in the following areas of personality traits (features):

\begin{tabular}{|l|c|c|c|}
\hline \multicolumn{1}{|c|}{ Personality Trait } & $\begin{array}{c}\text { Strongly } \\
\text { Agree }\end{array}$ & Agree & Disagree \\
\hline New recruits are able to take initiative & $\begin{array}{c}\text { Strongly } \\
\text { disagree }\end{array}$ \\
\hline New recruits are able to work under pressure & & & \\
\hline New recruits are able to think critically & & & \\
\hline New recruits have good management skills & & & \\
\hline New recruits have good organization skills & & \\
\hline New recruits are innovative (come up with new ideas) & & \\
\hline New recruits are reliable (depend on themselves) & & \\
\hline New recruits are flexible & & \\
\hline New recruits are punctual/on time & & \\
\hline New recruits have problem solving skills & & \\
\hline New recruits are able to leave personal problems at home & & \\
\hline New recruits dress appropriately & & \\
\hline New recruits enjoy a good sense of ethics & & \\
\hline
\end{tabular}

Question 9: Have you ever encountered a situation where you have had to offer the newly recruited engineers inhouse training to improve their employability skills (communication skills or personality traits)?

a. Yes

If yes, what issues did you cover?

b. $\mathrm{No}$

c. To some extent

If yes, what were the shortcomings? 
Question 10:Do you think universities should pay more attention to employability skills (communication and personality traits) along with the academic ones?
a. Yes
If yes, how?
b. No
c. To some extent 